\title{
Empowering Teaching Materials Of Approaches And Methods In English Language Teaching (Amelt) Subject Matter Through Lesson Study
}

\author{
Achmad Hilal Madjdi ${ }^{1}$, Atik Rokhayani ${ }^{2}$, Muh.Syafei $^{3}$ \\ \{Achmad.hilal@umk.ac.id¹ , atik.rokhayani@umk.ac.id², muh.syafei@umk.ac.id³\} \\ ${ }^{1,2,3}$ English Education Department, Universitas Muria Kudus PO BOX 53 Kudus 59327, Central Java \\ Indonesia
}

\begin{abstract}
This study is aimed at reconstructing the teaching materials of Approaches and Methods in English Language Teaching (AMELT) subject matter. This four semester credit- compulsory subject is taught to students of English Education Department of University of Muria Kudus, Central Java Indonesia to make them competence in teaching English as a foreign language to senior high school students. The design of the study is Research and Development and the overall development program was done in the framework of lesson study. The lecturer of this subject matter functioned as the researcher and reconstructed the teaching materials of AMELT. The finding of the study showed that lesson study empowered teaching materials of AMELT in at least three important points, a) sharing different teaching experience, b) sharing different pedagogical competence, and c) sharing teaching method and strategy. On the basis of the above finding, the researcher concluded that lesson study can practically empower the teaching material of AMELT.
\end{abstract}

Keyword: Lesson Study

\section{Introduction}

Developing teaching or learning materials of subjects matters is generally agreed by almost all scholars as a very valuable step in the teaching and learning process (Harsono, 2007; Nikoopour and Farsani, 2011; Rashidi, 2011). Common reasons for materials development usually start form a point of view that education as a political enterprise, should also be aware of their sociopolitical surroundings and to fight against the status quo, with the intent of transformation both in the classroom and in the larger society (Norton \& Toohey, 2004). Dealing with Norton and Toohey idea, teaching materials development can be programmed as a periodical activity which help teacher responds dynamically to the overall society problems, students' needs and political situation. In the other words, a teacher should always be sensitive and responsive as well to get success in teaching in learning process by scheduling teaching materials development as a tool to cope with sociopolitical environment which may influence educational activity.

Other studies for developing teaching materials were done by implementing sociolinguistic approach and multicultural context (Rokhman and Yuliat, 2010), practical undertaking (Harsono, 2007) and Lesson study (Nai, Degeng, Setyosari and Widianti, 2016). All approaches have their own benefits and positive impact, depend on the teaching materials 
which will be developed, the context which underlines the development and the purpose of the development. However, lesson study has been noticed as a good strategy to improve learning quality as well as teaching materials development as in one of the lesson study steps, discussion is done to improve teaching materials (Nai, Degeng, Setyosari and Widianti, 2016). The beneficial impact of lesson study to improve teaching quality and materials also proved by Nesusin, Intrarkhamhaeng, Supadol, Pienkes, and Poonpipthana (2013) in their research. They found that by implementing lesson study they did not only develop lesson plan, but also increased students achievement and students satisfaction score. This study was of course done under the consideration of the above idea. However, the main purpose was to gain better teaching materials of AMELT subject matter as well as to have better quality in teaching and learning process. Before having this study, the materials of AMELT subject matter were just compiled from several textbooks and other resources. The compiling materials were as a matter of fact good to give references to students. However, it needs some developments and inputs as teaching and learning English in Indonesia have been greatly developed due to the development of technology and global life.

Another consideration for materials development related to the fact that great movement to gain high quality and performance in high education in Indonesia, especially in a private University is a necessity. University of Muria Kudus, Central Java Indonesia is a private University and the English Education Department is one of the Department which educate English teacher candidates. Students of this department are hoped to be competent in teaching English in the setting of English as a Foreign Language. The AMELT subject matter is one of the compulsory subject they have to learned to provide them with teaching English competence for Senior High School students.

The contents of the subject matter provides students with theory and practice about approaches and methods in English language teaching and learning. The term approach will always flower discussion on teaching and learning a language because it has been long time ago stated by Antony (1963) that approach is a set of correlative assumptions dealing with the nature of language and the nature of language teaching and learning. This statement gives a clue of how a teacher handles a language teaching and learning process which is assumed to be greatly influenced by his or her assumption on the nature of language and language learning and teaching. In can be declared that the success of language teaching and learning may depends on the teacher's basic thinking on the subject matter being taught.

Antony's idea on a language teaching approach is supported by Richards and Rodgers (1986) who further state that there are three levels of consideration to understand what approach is. The first level deals with definition of approach as assumptions, beliefs, and theories about the nature of language and the nature of language learning. Those definitions are then consciously functioned and even operated as background knowledge or reference points. This function provides theoretical foundations for what language teachers always do and practice with learners in classrooms.

The second level has something to do with the system and design which specify the relationship $\mathrm{b}$ e t w e e $\mathrm{n}$ theories of language and learning. These relationships determine the form and function of instructional materials and activities in instructional settings. 
The third level, procedure, comprises the classroom techniques and practices which are consequences of particular approaches and designs. In other words, certain approach will end at applicable and specific procedures which can be adopted or practiced by any teacher in his or own class. Any observer then can also evaluate and judge if procedures being practiced belongs to the approach or not.

On the other hand, the discussion on methods cannot be separated from approaches, as a method always defined generally as a practical implementation of an approach. It is clear then, that any theory or even assumption on language and language learning will be realized through a method or methods in a classroom. In other words, as it is stated by Richards and Rodgers (2001), a method is theoretically related to approach which then practically realized in procedures. Richard and Rodger's statement is agreed by Brown (2001), who explained that a method is a generalized set of specification in the classroom for achieving linguistic objectives, method main concern is to teachers and learner role and behavior.

However, a teacher should consider many things before selecting a certain method for his or her teaching, such as the subject matter or skill to be taught, how he or she will take a role in his or her class, etc.

The problem is how to provide suitable teaching materials for English teacher candidates which will facilitate them not only the theoretical background knowledge but also other additional skills related to teaching and learning management. For this concern, this study was held under the frame work of lesson study as it has also been proved that lesson study has successfully improve teaching (Rock and Wilson, 2005; Cerbin and Kopp, 2006; Gómez, et.al, 2015). Another study has also proved the success on integrating lesson study in teaching practice of social study student teachers to improve the quality of learning (Towaf, 2016).

This study was done due to the need of providing teaching materials of AMELT subject matter with the spirit of improving student teacher competence on that subject matter. The framework of lesson study was chosen because of those consideration discussed above.

\section{Methodology}

\subsection{Research Approach}

The approach for developing model was Research and Development of the third level (Sugiyono, 2019) which is proposed by Borg and Gall (2003) in the simple procedures of seven steps, i.e. Preliminary research, Planning, Developing a draft of the product, Preliminary Field Testing, Product Revision, Main Field Testing, Revision. The simple procedures of model development was applied in this study with the reason that this study was also managed in the framework of lesson study which will cover the overall step of exploration and model development

\subsubsection{Preliminary Research}

This was done by investigating the gaps between the existing teaching materials and the needs of development. The activities included having literature review and small group discussion with some colleagues to get several inputs and ideas sharing. Some contributive points were also suggested by some English teacher at senior High Students, especially on developing materials of teacher character and competence. 


\subsubsection{Planning}

The results of Preliminary Research were then discussed more technically to have a plan to develop a new material which of course formed in the framework of accommodating the preview materials. In Planning, the approach and steps of lesson study were applied. The steps of lesson study applied in the model development were planning, doing/ seeing and reflecting (Lewis, 2002).

In the planning stage, the lecturer as the researcher conducted discussion on the aims of teaching and learning AMELT, the teaching materials and its development, the teaching and learning approach, strategy and method as well as the media. The result of the discussion was a new lesson design which was ready to be implemented. Above all, a new draft of teaching materials has also been ready to be discussed and learned with students.

In the doing/ seeing stage, the lecturer implemented the lesson design and the draft of teaching materials in teaching and learning activity. Some colleagues take roles as observers during the teaching and learning process. Nothings were done by the observers unless seeing (observing) and taking notes when they thought they needed to document something during the class to be discuss in the next stage.

In the reflecting stage, all participants discussed important issues, comments some other notes to clarify and reflect the teaching and learning process. The results of the discussion during the reflecting stage were very valuable to improve not only the teaching but also the final draft of the teaching materials. 


\subsubsection{Developing Initial Model/ Draft}

The initial draft of the teaching materials was then shared to get final contributions from other lecturers of AMELT or TEFL subject matter from another University. The procedure of model sharing was simple as it was included in teaching learning process of AMELT or TEFL subject matter there. The lecturer and the students were pleased to give contributions to the draft. They might also discuss the contents of the drafts, from the instructional purposes, materials development, discussion and example and evaluation. Any comment or contribution was very valuable to better the draft.

\subsubsection{Preliminary Field Testing}

The final draft of AMELT teaching materials was applied in teaching and learning process to get evaluation. In the class of AMELT, discussion was done with students to make them understand the overall materials development with the hope that they can take a proper position in teaching and learning process. The next is sharing the final draft to the department (in a small group discussion) to make sure that the final draft fulfills the program of the department. Field testing was also done by presenting points of development in an international conference.

\subsubsection{Revision}

Some notes were of course taken during the previous stages. Those are very significant and valuable inputs to revise the model/ the product. Lesson study was also applied again in the form a reflection discussion with the main goal of getting contribution to revise the model/ the product.

\subsubsection{Main Field Testing}

The revised draft was then field tested in the same department of a different University with the purpose of getting inputs or contributions from another institution which has different culture and academic atmosphere. The researchers took roles as observers during the main field testing.

\subsubsection{Final revision}

All contributions were considered important and properly examined and discussed in the final revision session. However, not all contributions were taken as new materials to revise the previous one. The final draft was then processed to got "ISBN" serial number.

\section{Findings and Discussion}

It is interesting to state here that the most valuable advantages of applying lesson study for materials development of AMELT subject matter was sharing activity which unexpectedly happen during the study which was done under the framework of lesson study. There were at least three sharing activities which were noted during this study, i.e. sharing different experience, different pedagogical competence and teaching method and strategy. 


\subsection{Sharing Different Teaching Experience.}

Teaching experience is unique as teachers have never have the same experience although they teach at the same school and the same years of teaching experience. The uniqueness is a result of a long time teaching service with different students, different academic atmosphere form year to year and different school culture. However, the discussion on teaching experience mostly worked in the area how to manage time allotment, manage classroom setting, select a proper teacher's role and set student and student interaction and student and teacher interaction.

Managing time allotment seems to be something simple and easy to do. Most of the participants in this study argue that they have never thought about it because their daily activities deal with consuming the time for teaching. The way they use their time is almost natural, just like letting everything runs in the way it has to run. Practicing this way, none of the participants feel wrong as teaching and learning process run well so far, and no complain from whoever, especially from the students.

Managing classroom setting is also interesting to discuss because it reflects the taste of the teacher in preparing the meeting with his or her students. It also reflects what roles the teacher will take during teaching and learning process. Teacher's role has something to do with students' role in the classroom because teacher's activities will consequently results on students and teacher interaction and students and students interaction.

\subsection{Sharing on Pedagogical competence,}

Pedagogical competence may support teachers' effort to master background knowledge and material resources which are very important for the success of teaching and learning activities. A teacher without knowledge may teach the concept incorrectly, and students may end up with the same incorrect belief as their teacher (Sadler et.al, 2013). Knowledge and resources sharing are therefore very important to build professional competence of the teacher.

According Mulyasa (2009), pedagogical competence is the ability of teachers in the management of education of students who at least include: 1) The ability to manage learning, 2) Understanding of the learners. 3) Design of learning. 4) Execution of educational learning and dialogue. 5) Utilization of Technology Education, 6) Evaluation of Learning Outcomes and 7) Development of learners.

However, the sharing on pedagogical competence in this study includes discussion on the novelty and the relevance of the theory with the content of teaching materials of the subject matter. The novelty of the theory will help both teacher and students to cope with newest learning problems which might not be faced by students who took the subject matter in the previous academic year. Students learning problems are usually different form year to year depends on the context of learning and the academic atmosphere which is developed at that academic year.

Fahruddin et al (2016) found that teachers' pedagogical competence have a positive influence directly and indirectly to the learning outcomes of students of economic high 
schools in East Lombok district in the academic year 2015/2016. This mean what has been shared by the participants during this study was really very valuable.

\subsection{Sharing teaching method and strategy}

The need for presenting and managing the language in a good circumstance is realized as a prior need by not only the teacher, but also by the students as well. As the most worldwidely learned second or foreign language, English is challenging for both students and teacher. Therefore, any meeting or discussion concerning with the teaching of the language is always interesting.

There are three popular methods which are implemented in foreign language classroom, i.e. Communicative Language Teaching (CLT), Grammar Translation Method (GTM) and Total Physical Response (TPR) (Intarapanith, 2012). Communicative Language Teaching (CLT) is the most popular method because it is claimed as the newest trend of teaching method which facilitates students to explore their learning. It is also stated that this method works well for improving students speaking skill. Grammar Translation Method (GTM) is a very well method which applied in English class in Indonesia with the assumption that the students will be easily facilitated in learning the foreign language if it is translated. Similarly, Total Physical Response (TPR) is also perceived as a motivational method because it integrates physical activity and language act.

\section{Conclusion}

Lesson study which was formerly created to improve teaching and learning quality has widely explored to other purposes, including developing teaching materials. This study has proved the significant role of lesson study to develop teaching materials of AMELT subject matter. The finding even proved that lesson study empowers teaching materials development of the subject matter. The overall steps of lesson study contributed significantly in designing the draft and the final product.

The functional contribution of Lesson study in empowering teaching materials development can be the roles and active participation of all participants. The excellent of lesson study is on the collaborative activities in the form of focus group discussion in the overall steps of lesson study. During focus group discussion, all participants shared concept, experience and idea to develop the materials, especially on the step of planning and reflecting.

\section{Acknowledgment}

Thanks to the Ministry of Research and High Education of the Republic of Indonesia. This paper is an additional outcome of the study which was funded by DRPM Kemenristek Dikti, the Republic of Indonesia. 


\section{References}

[1] Anthony, Edward M. 1963. Approach, Method, and Technique. English Learning 17: 6367. An Arbor: University of Michigan Press.

[2] Borg R Walter, Gall D Meredith. Educational Research. Longman, New York. (2003).

[3] Cerbin, William and Bryan Kopp. Lesson Study as a Model for Building pedagogical Knowledge and Improving Teaching. International Journal of Teaching and Learning in Higher Education.Vol.18, No 3, 250-257. ISSN 1812-9129. (2006).

[4] Fahruddin, Martono, T, and Murtini, W. The Effect of Pedagogic Competency, Personality, Professional and Social Competency Teacher to Study Achievement of Economic Lesson in State Senior High School of East Lombok District Academic Year 2015/2016 . Proceeding The 2nd International Conference On Teacher Training and Education Sebelas Maret University. Volume 2 Number 1. ISSN : $25002-4124$. ( 2016)

[5] Gómez, Encarna Soto , María J. Serván Núñez, Angel I Pérez Gómez, Noemi Peña Trapero, "Lesson study and the development of teacher's competences: From practical knowledge to practical thinking", International Journal for Lesson and Learning Studies, Vol. 4 Issue: 3, pp.209-223, https://doi.org/10.1108/IJLLS-09-2014-0034. (2015)

[6] Harsono. Y.M. Developing Materials for Specific Purposes. TEFLIN Journal, Volume 18, Number 2. ( 2007)

[7] Intarapanich, Chutima. Teaching Methods, Approaches and Strategies Found in EFL Classrooms: A Case Study in Lao PDR. Procedia - Social and Behavioral Sciences 88 . $306-311 .(2013$ )

[8] Lewis, C. Lesson study: A handbook of teacher-led instructional change. Philadelphia: Research for Better Schools. (2002)

[9] Mulyasa. Teachers Competency Standards and Certification. Bandung: PT Youth Rosdakarya. (2009)

[10] Nai, Firmina Angela., Degeng, I Nyoman Sudana., Setyosari, Punaji., and Widiati, Utami. Teaching Material Development of Learning and Teaching Course Through Lesson Study Application for University Students. A Proceeding on International Conference On Education: Education in the 21th Century: Responding to Current Issues. (2016)

[11] Nesusin, N., Intrarkhamhaeng P.,, Supadol P., , Pienkes, and Poonpipthana, S. Development of lesson plans by the lesson study approach for the 6th grade students in social study subject based on open approach innovation. Procedia - Social and Behavioral Sciences 116 ( 2014 ) 1411 - 1415.(2014)

[12 ] Nikoopour, J, and Farsani,MA. English Language Teaching Material Development. Journal of Language and Translation Volume 2, Number 2, (pp.1-12). ( 2011)

[13 Norton, B., \& Toohey, K. Critical pedagogies and language learning: an introduction. In B. Norton \& K. Toohey (Eds.), Critical pedagogies and language learning (pp. 1-17). Cambridge: Cambridge University Press. (2004)

[14] Rokhman, Fathur and Yuliati. The development of the Indonesian teaching material based on multicural context by using sociolinguistic approach at junior high school. Procedia Social and Behavioral Sciences 9 1481-1488. 5

[15] Rashidi, Nasser. A Model for EFL Materials Development within the Framework of Critical Pedagogy (CP). English Language Teaching Vol. 4, No. 2; June (2011)

[16] Richards and Rodgers. Approaches and Methods in Language Teaching. Cambridge: Cambridge University Press. (1986) 
[17] Richards, J.C. \& Rodgers, T.S. Approaches and methods in language teaching (2nd ed.). Cambridge: Cambridge University Press. (2001).

[18] Rock, Tracy C. \& Cathy Wilson. ImprovingTeaching through Lesson Study. Teacher Education Quarterly, Winte.(2005)

[19] Sadler Philip M., Sonnert Gerhard., Coyle, Harold P., Smith Nancy Cook., Miller, Jaimie L. The Influence of Teachers' Knowledge on Student Learning in Middle School Physical Science Classrooms. American Educational Research Journal., Vol. 50, No. 5, pp. 1020-1049 DOI: 10.3102/0002831213477680, October. ( 2013)

[20] Sugiyono. Metoda Penelitian dan Pengembangan. Alfabeta, Bandung. (2019).

[21] Towaf, Siti Malikhah. Integration of Lesson Study in Teaching Practice of Social Study Student Teachers to Improve the Quality of Learning and Promote a Sustainable Lesson Study. Journal of Education and Practice. ISSN 2222-1735 (paper), 2222-288X (on line).Vol.7, No.18. (2016) 